\title{
Palliative radiotherapy in patients with a symptomatic pelvic mass of metastatic colorectal cancer
}

Sun Hyun Bae ${ }^{1}$, Won Park ${ }^{1 *}$, Doo Ho Choi ${ }^{1}$, Heerim Nam², Won Ki Kang ${ }^{3}$, Young Suk Park ${ }^{3}$, Joon Oh Park Ho Kyung Chun ${ }^{4}$, Woo Yong Lee ${ }^{4}$, Seong Hyeon Yun ${ }^{4}$ and Hee Cheol Kim ${ }^{4}$

\begin{abstract}
Background: To evaluate the palliative role of radiotherapy (RT) and define the effectiveness of chemotherapy combined with palliative RT (CCRT) in patients with a symptomatic pelvic mass of metastatic colorectal cancer.

Methods: From August 1995 to December 2007, 80 patients with a symptomatic pelvic mass of metastatic colorectal cancer were treated with palliative RT at Samsung Medical Center. Initial presenting symptoms were pain (68 cases), bleeding (18 cases), and obstruction (nine cases). The pelvic mass originated from rectal cancer in 58 patients (73\%) and from colon cancer in 22 patients (27\%). Initially 72 patients (90\%) were treated with surgery, including 64 complete local excisions; $77 \%$ in colon cancer and $81 \%$ in rectal cancer. The total RT dose ranged 860 Gy (median: 36 Gy) with 1.8-8 Gy per fraction. When the $\boldsymbol{\alpha} / \boldsymbol{\beta}$ for the tumor was assumed to be 10 Gy for the biologically equivalent dose (BED), the median RT dose was 46.8 Gy $y_{10}$ (14.4-78). Twenty one patients (26\%) were treated with CCRT. Symptom palliation was assessed one month after the completion of RT.
\end{abstract}

Results: Symptom palliation was achieved in $80 \%$ of the cases. During the median follow-up period of five months (1-44 months), 45\% of the cases experienced reappearance of symptoms; the median symptom control duration was five months. Median survival after RT was six months. On univariate analysis, the only significant prognostic factor for symptom control duration was BED $\geq 40 \mathrm{~Gy}_{10}(\mathrm{p}<0.05)$, and CCRT was a marginally significant factor $(p=0.0644)$. On multivariate analysis, BED and CCRT were significant prognostic factors for symptom control duration $(p<0.05)$.

Conclusions: RT was an effective palliation method in patients with a symptomatic pelvic mass of metastatic colorectal cancer. For improvement of symptom control rate and duration, a BED $\geq 40 \mathrm{~Gy}_{10}$ is recommended when possible. Considering the low morbidity and improved symptom palliation, CCRT might be considered in patients with good performance status.

Keywords: metastatic colorectal cancer, pelvic recurrence, palliative radiation therapy, concurrent chemoradiotherapy

\section{Background}

Local recurrence of colorectal cancer after surgery occurred in 10-40\% of patients [1-4]. Although local control has been improved with adjuvant chemotherapy and radiotherapy (RT), approximately $10-25 \%$ of patients still develop recurrence of disease in the pelvis [5-7].

\footnotetext{
* Correspondence: wonro.park@samsung.com 'Department of Radiation Oncology, Samsung Medical Center, Sungkyunkwan University School of Medicine, Seoul, Korea Full list of author information is available at the end of the article
}

Pelvic recurrence contributes significantly to the clinical course and is one of the major problems affecting the quality of life in these patients $[8,9]$.

The role of primary tumor resection for non-curable stage IV colorectal cancer remains undefined. Kleespies et al. reported that palliative resection was associated with a particularly unfavorable outcome in rectal cancer patients presenting with locally advanced lesion expected macroscopic residual tumor or an extensive comorbidity [10]. Patients with prior curative resection

\section{Biomed Central}

(c) 2011 Bae et al; licensee BioMed Central Ltd. This is an Open Access article distributed under the terms of the Creative Commons Attribution License (http://creativecommons.org/licenses/by/2.0), which permits unrestricted use, distribution, and reproduction in any medium, provided the original work is properly cited. 
of colorectal cancer often present with pelvic pain, one of the common manifestations of local recurrence involving nerves in the presacrum or pelvic sidewalls. The surgical approach to relieve symptomatic pain in the pelvis is usually unlikely to have negative resection margins [11]. Accordingly, resection of symptomatic pelvic tumor may be warranted only in those with adequate performance status and a resectable tumor burden with a possibly negative resection margin.

RT has been considered an effective palliative treatment for patients with symptomatic pelvic tumors of colorectal cancer. Previous studies have used RT as palliative treatment to relieve pelvic symptoms in heterogeneous patients $[9,11-23]$. These studies included patients with unresectable local recurrence after definitive surgery and symptomatic local recurrence with distant metastasis. Recently, modern combination chemotherapy including targeted drugs has been used to treat patients with metastatic colorectal cancer patients [24,25]. Although these drugs might be effective for symptomatic palliation in responding patients, the role of $\mathrm{RT}$ in addition to chemotherapeutic or targeted drugs for palliation is controversial. To date, there have been few reports of the synergistic effect of concurrent chemoradiotherapy (CCRT) with palliative intent in gastrointestinal cancer [22,26-30].

In this study, we evaluated the palliative role of RT and defined the effectiveness of chemotherapy combined with palliative RT in patients with a symptomatic pelvic mass of metastatic colorectal cancer.

\section{Methods}

From August 1995 to December 2007, we retrospectively reviewed 80 patients with a symptomatic pelvic mass of metastatic colorectal cancer who were treated with palliative RT at Samsung Medical Center. All patients had disease outside the pelvis and consulted a radiation oncologist for symptomatic palliation.

Fifty-eight patients $(73 \%)$ were initially diagnosed with rectal cancer and 22 patients $(27 \%)$ with colon cancer. Seventy-two patients (90\%) were treated with surgery, including 64 complete local excisions (52 curative surgeries). Eight patients (10\%) received chemotherapy alone. Twenty-two patients (27\%) received adjuvant RT after curative surgery or salvage RT after local recurrence. The RT dose ranged from 40Gy to 74Gy with 1.8-2.0 Gy per fraction.

Patient age at the time of palliative RT for symptomatic pelvic mass ranged from 27 to 85 years (median 57 years). There were 43 males (54\%) and 37 females (46\%). Eastern Cooperative Oncology Group (ECOG) performance scores were 0 in one patient (1\%), 1 in 28 (35\%), 2 in 36 (45\%), 3 in $13(16 \%)$, and 4 in two (3\%) patients. Forty patients (50\%) had single organ metastasis regardless of the number of metastatic nodules, and 40 patients (50\%) had two or more organ metastases. The common metastatic sites were liver (33 patients, $41 \%)$, lung $(29,36 \%)$, paraaortic lymph node $(27,34 \%)$, and peritoneal seeding $(15,19 \%)$.

Eighty patients had 95 cases of clinical symptoms. The most common clinical symptom was pain $(68,72 \%)$, followed by rectal bleeding in 18 cases (19\%), and obstructive symptoms in nine cases (9\%). Six patients had two concurrent symptoms, pain and bleeding (five patients) or pain and obstruction (one patient). Seven patients experienced pain recurrence after palliative RT and received palliative re-RT. In these patients, evaluation of the response to palliative re-RT was available, and all cases were independently included in the analysis of symptom response to palliative RT.

RT was administered using 6-15 MV photon beams from linear accelerators. The radiation field included the recurrent mass of the pelvic cavity with $2-3 \mathrm{~cm}$ margins. Different RT doses were used according to the patient's performance status and extra-pelvic tumor burden. The median RT dose was 36 Gy (8-60 Gy). All patients received $\mathrm{RT}$ once daily, and the dose per fraction ranged from 1.8 Gy to 8.0 Gy (median 2.5 Gy). The total RT doses were converted into the biologically equivalent dose (BED) for comparison. When $\boldsymbol{\alpha} / \boldsymbol{\beta}$ was assumed to be $10 \mathrm{~Gy}$, the median total BED was $46.8 \mathrm{~Gy}_{10}$ (14.4$\left.78.0 \mathrm{~Gy}_{10}\right)$.

Twenty-one patients (26\%) received CCRT with the following regimens: capecitabine in eight patients, fluorouracil in six patients, oral tegafur-uracil in five patients, and combination regimen in two patients. Thirty-one cases received further chemotherapy after completion of palliative RT. Patient and treatment characteristics are shown in Table 1.

Symptom palliation was assessed one month after the completion of palliative RT. For patients with pain as the presenting symptom, effective palliation was defined as decreased or resolved pain or decreased analgesia. For patients with bleeding, effective palliation was defined as improved hemoglobin, stable hemoglobin, resolved hematochesia, or normalized hemoglobin. For patients with obstruction, effective palliation was defined as improved or resolved constipation, decreased laxative use, or no need for intervention such as a stent or colostomy.

The follow-up period was defined as the time from the start of palliative RT until progression of symptom or death. Toxicity was assessed according to the Common Terminology Criteria for Adverse Events (CTCAE) version 3.0.

Survival rates were estimated with the Kaplan-Meier method, and comparisons between the groups were determined using the log-rank test [31]. Multivariate analysis was performed to assess the relationships 
Table 1 Patient and treatment characteristics

\begin{tabular}{|c|c|}
\hline Characteristic & No. of patients (\%) \\
\hline Age & Median: 57 years \\
\hline$<60$ years & $43(54)$ \\
\hline$\geq 60$ years & $37(46)$ \\
\hline \multicolumn{2}{|l|}{ Gender } \\
\hline Male & $43(54)$ \\
\hline Female & $37(46)$ \\
\hline \multicolumn{2}{|l|}{$\mathrm{ECOG}^{*}$ performance status } \\
\hline $0-2$ & $65(81)$ \\
\hline $3-4$ & $15(19)$ \\
\hline \multicolumn{2}{|l|}{ Primary site } \\
\hline Colon cancer & $22(27)$ \\
\hline Rectal cancer & $58(73)$ \\
\hline \multicolumn{2}{|l|}{ Status of distant metastasis } \\
\hline Single organ involved & $40(50)$ \\
\hline Multiple organs involved & $40(50)$ \\
\hline \multicolumn{2}{|l|}{ Symptom ${ }^{b}$} \\
\hline Pain & $68(72)$ \\
\hline Bleeding & $18(19)$ \\
\hline Obstruction & $9(9)$ \\
\hline \multicolumn{2}{|l|}{ Re-irradiation $^{\dagger}$} \\
\hline Yes & $30(32)$ \\
\hline No & $65(68)$ \\
\hline \multicolumn{2}{|l|}{ Biologically equivalent dose $^{\dagger}$} \\
\hline$<40 \mathrm{~Gy}_{10}$ & $34(36)$ \\
\hline$\geq 40 \mathrm{~Gy}_{10}$ & $61(64)$ \\
\hline \multicolumn{2}{|l|}{ Concurrent chemotherapy $^{\dagger}$} \\
\hline Yes & $22(23)$ \\
\hline No & $73(77)$ \\
\hline \multicolumn{2}{|l|}{ Adjuvant chemotherapy ${ }^{\dagger}$} \\
\hline Yes & $31(33)$ \\
\hline No & $64(67)$ \\
\hline
\end{tabular}

* ECOG: Eastern Cooperative Oncology Group.

${ }^{\dagger}$ Treatment characteristics: 80 patients had 95 cases of clinical symptoms.

between the outcomes and possible prognostic variables using the Cox proportional hazards model [32]. The Chi-square test was used to analysis differences in patient and treatment characteristics between the symptom control group and the recurrent group. Statistical analyses were performed using SAS software (SAS for Windows, version 9.0, SAS Institute, Cary, NC, USA).

\section{Results}

The median follow-up time was five months (range, 144 months). The overall survival rate at one year was $22.1 \%$, and the median survival was six months. Overall symptomatic palliation was achieved in 76 of 95 cases (80\%). Forty-three cases (45\%) experienced recurrence of symptoms, and the median symptom control duration was five months (range, 1-44 months).

In 80 patients, 68 cases had the symptom of pain; 54 cases (79\%) achieved palliation of pain and 35 cases
(51\%) experienced reappearance of pain. Eighteen cases had the symptom of bleeding; 15 cases (83\%) achieved palliation of bleeding and five cases (28\%) experienced reappearance of bleeding. Nine cases had the symptom of obstruction; seven cases (78\%) achieved palliation of obstruction, and three cases (33\%) experienced reappearance of obstruction.

Figure 1 shows symptom control rates according to initial presenting symptom. One-year symptomatic control rates were $32.1 \%, 69.9 \%$, and $37.5 \%$ for pain, bleeding, and obstruction, respectively. Table 2 shows the recurrence rate after symptom palliation. BED was a statistically significant factor affecting recurrence after symptom palliation $(\mathrm{p}=0.0011)$. For $\mathrm{BED}<40 \mathrm{~Gy}_{10}, 23$ of 34 cases $(68 \%)$ had recurrence and for BED $\geq 40$ $\mathrm{Gy}_{10}$, and 20 of 61 cases (33\%) had recurrence.

On univariate analysis, the only significant prognostic factor for symptom control rate was BED ( $p=0.0089)$, and CCRT was a marginally significant factor $(\mathrm{p}=$ 0.0644) (Table 3). In patients with pain, higher BED and CCRT was associated with improved outcome with statistical significance. In patients with bleeding, only higher BED was statistically significant factor. In nine patients with obstruction, there was no significant factor associated with symptom relief. Figure 2 shows differences in the symptom control rate according to BED and CCRT. Multivariate Cox regression analysis of prognostic factors for the symptom control rate revealed that higher RT dose (BED $\geq 40 \mathrm{~Gy}_{10}$, hazard ratio; 0.503, $\mathrm{p}=$ 0.0406) and CCRT (hazard ratio; 0.427, $\mathrm{p}=0.0449$ ) were favorable factors.

All patients tolerated the palliative treatment. Thirtyeight patients experienced nausea, diarrhea, cystitis, or perineal skin reaction of grade 1 or 2 during treatment. There was no significant difference of treatment related toxicity between RT alone and CCRT ( $45 \%$ vs. $52 \%$, p = 0.4380 ). There was no severe toxicity above grade 3 or treatment-related deaths.

\section{Discussion}

External RT has been considered an effective palliative treatment in patients with an unresectable pelvic mass of colorectal cancer. Studies reported in the 1960s1980s showed that relief of pain and/or bleeding was achieved in approximately $75 \%$ of patients with doses as low as $20 \mathrm{~Gy}$ in ten fractions over two weeks or various doses of 40-60Gy in 1.8-2.5 Gy per fraction [11-20]. Median duration of symptom relief was only 6-9 months. Later reports showed similar or improved results of symptom palliation: control of pain in 78-93\% of patients, control of bleeding in $68-100 \%$, and control of mass in 35-88\% [9,21-23]. The rate and duration of symptom palliation in our study were similar to those of previous reports. 
Be et al. Radiation Oncology 2011, 6:52

Page 4 of 8 http://www.ro-journal.com/content/6/1/52

(a)

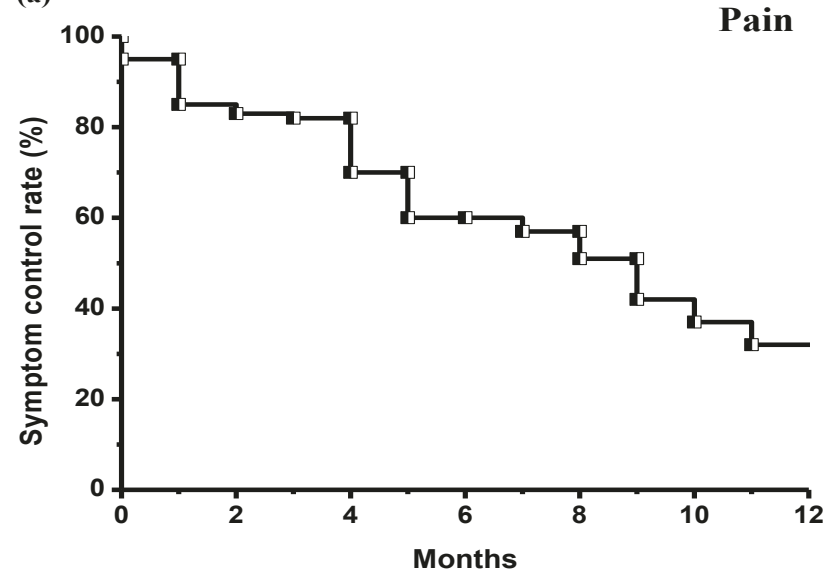

(b)

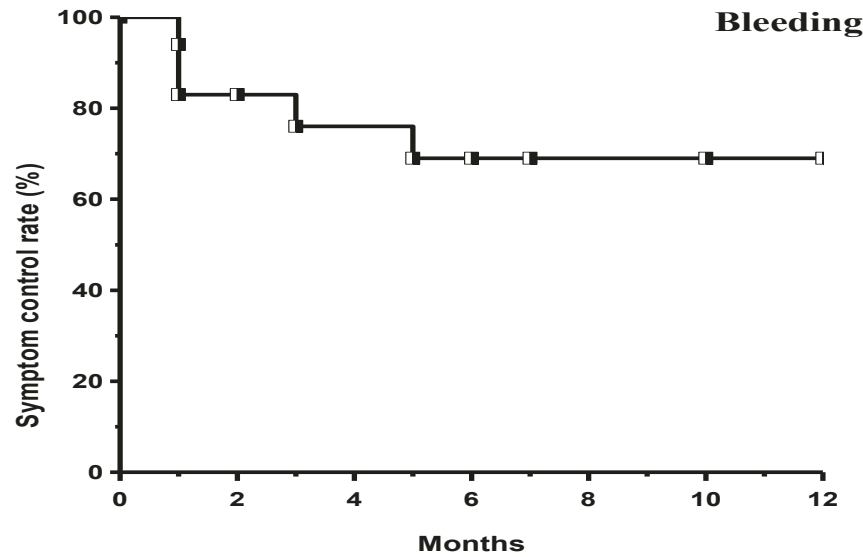

(c)

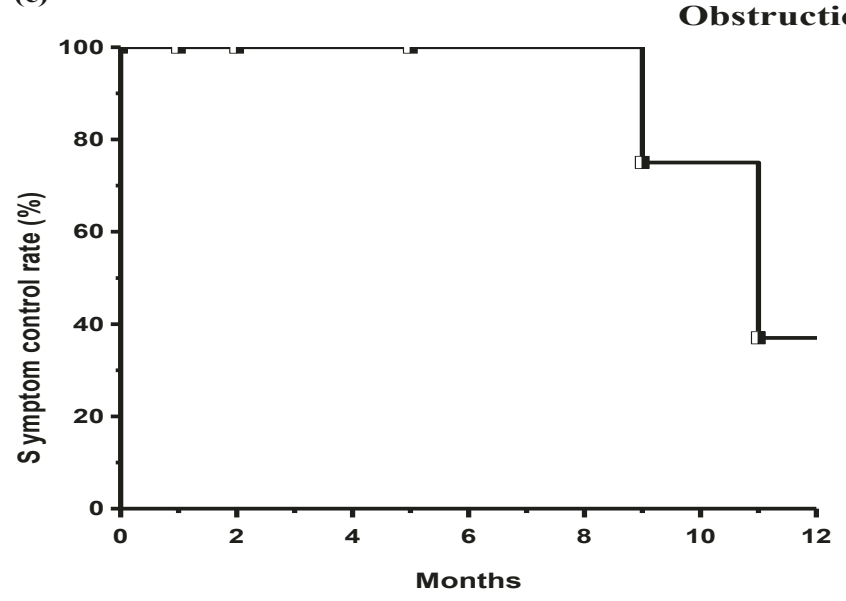

Figure 1 Symptom control rates according to initial presenting symptom. (a) pain, (b) bleeding, (c) obstruction. 
Table 2 Symptom recurrences according to patient and treatment characteristics in patients with palliative symptom control after palliative treatment

\begin{tabular}{|c|c|c|c|}
\hline Characteristic & $\begin{array}{l}\text { Total control } \\
\text { number }\end{array}$ & $\begin{array}{l}\text { Recurrence } \\
(\%)\end{array}$ & $\mathrm{p}$-value \\
\hline \multicolumn{4}{|l|}{ Symptom } \\
\hline Pain & $33(49)$ & $35(51)$ & 0.1499 \\
\hline Bleeding & $13(72)$ & $5(28)$ & \\
\hline Obstruction & $6(67)$ & $3(33)$ & \\
\hline \multicolumn{4}{|l|}{ Re-irradiation } \\
\hline Yes & $16(53)$ & $14(47)$ & 0.8519 \\
\hline No & $36(55)$ & $29(45)$ & \\
\hline \multicolumn{4}{|l|}{$\begin{array}{l}\text { Biologically equivalent } \\
\text { dose }\end{array}$} \\
\hline$<40 \mathrm{~Gy}_{10}$ & $11(32)$ & $23(68)$ & 0.0011 \\
\hline$\geq 40 \mathrm{~Gy}_{10}$ & $41(67)$ & $20(33)$ & \\
\hline \multicolumn{4}{|l|}{$\begin{array}{l}\text { Concurrent } \\
\text { chemotherapy }\end{array}$} \\
\hline Yes & $14(44)$ & $8(36)$ & 0.3387 \\
\hline No & $38(52)$ & $35(48)$ & \\
\hline
\end{tabular}

Some data suggest a correlation between RT dose and the effect of palliation. Wong CS et al. [9] reported the response rate of pelvic symptoms according to RT dose. There was a trend suggesting increased response rates with increasing total RT dose. For pain improvement after RT, $48 \%$ of patients responded after a total dose of less than $20 \mathrm{~Gy}, 77 \%$ responded after a dose of 20-30 Gy, $79 \%$ after $30-45$ Gy, and $89 \%$ after 45 Gy or more. For residual, inoperable, or recurrent lesions, Wang CC and Schulz MD [17] reported that the percentage of patients with controlled symptoms for six months or more increased with dose (12\% with $21-30$ Gy, $31 \%$ with 31-40 Gy, and 58\% with 41-50 Gy). Crane $\mathrm{CH}$ et al. [22] used hypofractionated RT with three different dose regimens (30 Gy/6 fractions, 35 Gy/14 fractions and 45 Gy/ 25 fractions). On univariate analysis, BED $<35 \mathrm{~Gy}_{10}$ showed a higher risk of pelvic symptomatic progression when $\alpha / \beta$ was assumed to be $10 \mathrm{~Gy}(\mathrm{p}=0.009)$. In our study, the overall symptom control rate and the oneyear symptom control rate were $69 \%$ and $40.5 \%$ respectively for BED $\geq 40 \mathrm{~Gy}_{10}$ and $32 \%$ and $28.5 \%$ for BED < $40 \mathrm{~Gy}_{10}$. Since BED was a significant prognostic factor for symptom control rate, it might be better to treat with a higher RT dose to increase the palliation rate and symptom control duration.

In the pelvic cavity, the tolerance dose of normal tissue is a limiting factor when determining the RT dose. The small bowel, which is regarded as one of the most sensitive organs to RT, has a tolerance dose of TD 5/5 with a dose of 50 Gy for $1 / 3$ small bowel irradiation and TD 50/5 with a dose of 60 Gy [33]. The risk of injury to the bowel is increased in cases with a history of previous surgery. However, there is evidence suggesting that
Table 3 Univariate analysis of factors affecting symptom control rate in 95 cases

\begin{tabular}{|c|c|c|}
\hline Characteristic & $\begin{array}{c}\text { One-year symptom control } \\
\text { rate }(\%)\end{array}$ & p-value \\
\hline \multicolumn{3}{|l|}{ Age } \\
\hline$<60$ years & 22.6 & 0.5121 \\
\hline$\geq 60$ years & 46.8 & \\
\hline \multicolumn{3}{|l|}{ Gender } \\
\hline Male & 45.1 & 0.1210 \\
\hline Female & 29.2 & \\
\hline \multicolumn{3}{|l|}{$\begin{array}{l}\text { ECOG* performance } \\
\text { status }\end{array}$} \\
\hline $0-2$ & 36.2 & 0.8387 \\
\hline $3-4$ & 27.0 & \\
\hline \multicolumn{3}{|l|}{ Primary site } \\
\hline Colon cancer & 38.8 & 0.9967 \\
\hline Rectal cancer & 37.8 & \\
\hline \multicolumn{3}{|l|}{ Symptom } \\
\hline Pain & 32.1 & 0.1029 \\
\hline Bleeding & 69.9 & \\
\hline Obstruction & 37.5 & \\
\hline \multicolumn{3}{|l|}{$\begin{array}{l}\text { Biologically equivalent } \\
\text { dose }\end{array}$} \\
\hline$<40 \mathrm{~Gy}_{10}$ & 28.5 & 0.0089 \\
\hline$\geq 40 \mathrm{~Gy}_{10}$ & 40.5 & \\
\hline \multicolumn{3}{|l|}{ Re-irradiation } \\
\hline Yes & 41.0 & 0.3750 \\
\hline No & 36.5 & \\
\hline \multicolumn{3}{|l|}{$\begin{array}{l}\text { Concurrent } \\
\text { chemotherapy }\end{array}$} \\
\hline Yes & 61.3 & 0.0644 \\
\hline No & 33.2 & \\
\hline \multicolumn{3}{|l|}{ Adjuvant chemotherapy } \\
\hline Yes & 32.2 & 0.1986 \\
\hline No & 46.8 & \\
\hline
\end{tabular}

* ECOG: Eastern Cooperative Oncology Group.

significant recovery of the RT effect occurs with time $[23,34]$. Nieder $C$ et al. [34] reported that acute responding tissues recovered from radiation injury within a few months and could then tolerate another full course of radiation. For late toxicity endpoints, the skin, mucosa, lung, and spinal cord do partially recover from subclinical injury at a magnitude dependent on the organ type, size of the initial dose, and, to a lesser extent, the interval between radiation courses. Mohiuddin M et al. [23] reported long term results of re-RT for patients with recurrent rectal cancer. They suggested a re-RT dose according to the interval between previous RT and reRT as follows: 35 Gy for an interval of 3-12 months, 4045 Gy for 12-24 months, 45-50 Gy for 24-36 months, and 50-55 Gy for more than 36 months. In our study, $27 \%$ of patients received re-RT, and there was no severe toxicity, including RT-induced fistula. 


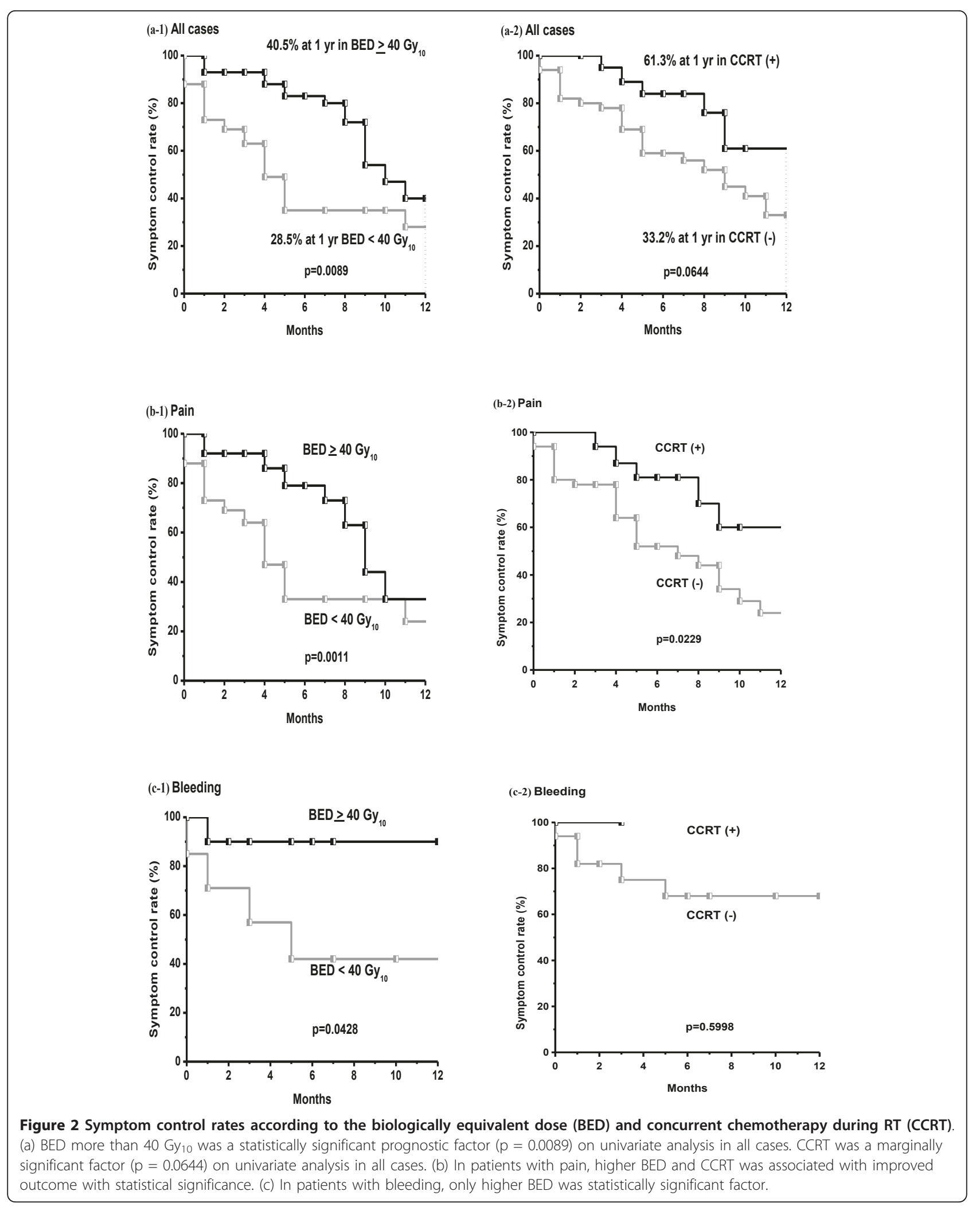


There are a few studies on CCRT for palliative intent in patients with distant metastasis. Wong CS et al. [9] reviewed 519 patients with locally recurrent rectal cancer treated with RT. Concurrent extrapelvic distant metastases were found in 164 patients. Twenty-two patients received CCRT with 5-fluorouracil and mitomycin $C$ in a pilot study of combined modality therapy. Ten of the 22 patients were unable to complete the treatment protocol because of excessive acute hematological and gastrointestinal toxicity, and five patients developed neutropenic sepsis, one of whom died [35]. Crane $\mathrm{CH}$ et al. [22] first described the use of CCRT as an initial measure in 80 patients with synchronous distant metastasis from rectal cancer. Symptoms from the primary tumor resolved in $94 \%$ of cases, and progression occurred at a median of 33 weeks. There were acute complications of Radiation Therapy Oncology Group (RTOG) Grade 3 or greater in four patients, severe perioperative complications in five patients, and no significant late treatment-related complications. They concluded that initial pelvic CCRT produced high pelvic symptom control rates and that patients can be safely treated using this modality. In a study of the clinical benefit of palliative CCRT in advanced gastric cancer, 37 patients were treated with palliative RT (median dose $35 \mathrm{~Gy}$ ) and nearly two-thirds of all patients received CCRT [26]. The overall symptom control rate was approximately $70 \%$, which was superior to the previous 25-54\% control rate for palliative RT alone [36]. Some studies reported the benefit of palliative CCRT for dysphagia in advanced esophageal cancer [27-30]. A phase I/II trial from Canada [29] prospectively treated 22 patients with dysphagia from advanced incurable esophageal cancer with palliative RT (30 Gy/10 Fractions) and a concurrent single course of chemotherapy (5-FU and mitomycin-C). Treatment was generally well tolerated and $68 \%$ achieved a complete response. The median dysphagia-free interval from time of onset of improvement was 11 weeks, and 11 patients (73\%) remained dysphagia-free until death. They concluded that a short course of radiotherapy plus chemotherapy might produce complete relief of swallowing difficulties in a substantial proportion of patients with acceptable toxicity. In our study, the overall symptom control rate and one-year symptom control rate were $64 \%$ and $61.3 \%$, respectively, in CCRT and $52 \%$ and $33.2 \%$ in RT alone. There were no severe complications in the CCRT group.

Our study has some limitations. First, this study was retrospectively analysis. It had heterogeneous patient's group and radiation dose. The results may be affected by the selection biases. Second, this study was performed in a small sample size. To conclude the effectiveness of the higher $\mathrm{BED} \geq 40 \mathrm{~Gy}_{10}$ and CCRT to symptomatic pelvic recurrence, prospective randomized trial might be needed.

\section{Conclusions}

In patients with a pelvic mass combined with distant metastasis, symptom palliation was achieved in $80 \%$ of the cases, and the median symptom control duration was five months. For improvement of symptom control rate and duration, a higher $\mathrm{BED} \geq 40 \mathrm{~Gy}_{10}$ is recommended when possible. Considering the low morbidity with CCRT and improved symptom palliation, CCRT might be considered in patients with good performance status.

\section{Author details}

${ }^{1}$ Department of Radiation Oncology, Samsung Medical Center, Sungkyunkwan University School of Medicine, Seoul, Korea. ${ }^{2}$ Department of Radiation Oncology, Kangbuk Samsung Medical Center, Sungkyunkwan University School of Medicine, Seoul, Korea. ${ }^{3}$ Department of Medicine (Division of Hematology/Oncology), Samsung Medical Center,

Sungkyunkwan University School of Medicine, Seoul, Korea. ${ }^{4}$ Department of General Surgery, Samsung Medical Center, Sungkyunkwan University School of Medicine, Seoul, Korea.

\section{Authors' contributions}

WP made contribution to conception and design of the study, and revised the manuscript. SHB contributed to acquisition of data, analysis and interpretation of data, and drafted the manuscript. DHC and HN helped in literature research and revision of the manuscript. YSP, JOP, WYL, SHY and HCK participated in design of study. WKK and HKC gave some intellectual recommendation. All authors have read and approved the final manuscript.

\section{Competing interests}

The authors declare that they have no competing interests.

Received: 29 January 2011 Accepted: 21 May 2011

Published: 21 May 2011

\section{References}

1. Rao AR, Kagan AR, Chan PM, Gilbert HA, Nussbaum H, Hintz BL: Patterns of recurrence following curative resection alone for adenocarcinoma of the rectum and sigmoid colon. Cancer 1981, 48(6):1492-5.

2. Phillips RK, Hittinger R, Blesovsky L, Fry JS, Fielding LP: Local recurrence following 'curative' surgery for large bowel cancer: II. The rectum and rectosigmoid. Br J Surg 1984, 71:17-20.

3. Pilipshen SJ, Heilweil M, Quan SH, Sternberg SS, Enker WE: Patterns of pelvic recurrence following definitive resections of rectal cancer. Cancer 1984, 53:1354-1362.

4. Douglass HO Jr, Moertel CG, Mayer RJ, Thomas PR, Lindblad AS, Mittleman A, Stablein DM, Bruckner HW: Survival after postoperative combination treatment of rectal cancer. N Engl J Med 1986, 315:1294-1295.

5. Fisher B, Wolmark N, Rockette H, Redmond C, Deutsch M, Wickerham DL, Fisher ER, Caplan R, Jones J, Lerner H, Gordon P, Feldman M, Cruz A, Legault-Poisson S, Wexler M, Lawrence W, Robidoux A, Other NSABP investigators: Postoperative adjuvant chemotherapy or radiation therapy for rectal cancer: results from NSABP protocol R-01. J Natl Cancer Inst 1988, 80(1):21-9.

6. Gérard A, Buyse M, Nordlinger B, Loygue J, Pène F, Kempf P, Bosset JF, Gignoux M, Arnaud JP, Desaive C, Duez N: Preoperative radiotherapy as adjuvant treatment in rectal cancer. Final results of a randomized study of the European Organization for Research and Treatment of Cancer (EORTC). Ann Surg 1988, 208(5):606-14.

7. Krook JE, Moertel CG, Gunderson LL, Wieand HS, Collins RT, Beart RW, Kubista TP, Poon MA, Meyers WC, Mailliard JA, Twito DI, Morton RF, Veeder MH, Witzig TE, Cha S, Vidyarthi SC: Effective surgical adjuvant therapy for high-risk rectal carcinoma. N Engl J Med 1991, 324(11):709-15. 
8. Lybeert ML, Martijn H, de Neve W, Crommelin MA, Ribot JG: Radiotherapy for locoregional relapses of rectal carcinoma after initial radical surgery: definite but limited influence on relapse-free survival and survival. Int J RadiatOncolBiolPhys 1992, 24(2):241-6.

9. Wong CS, Cummings BJ, Brierley JD, Catton CN, McLean M, Catton P, Hao Y: Treatment of locally recurrent rectal carcinoma-results and prognostic factors. Int J RadiatOncolBiolPhys 1998, 40(2):427-35.

10. Kleespies A, Füessl KE, Seeliger H, Eichhorn ME, Müller MH, Rentsch M, Thasler WE, Angele MK, Kreis ME, Jauch KW: Determinants of morbidity and survival after elective non-curative resection of stage IV colon and rectal cancer. Int J Colorectal Dis 2009, 24(9):1097-109, Epub 2009 Jun 3.

11. Willett CG, Gunderson LL: Palliative treatment of rectal cancer: is radiotherapy alone a good option? J Gastrointest Surg 2004, 8(3):277-9.

12. Gunderson LL, Martenson JA: Irradiation of adenocarcinomas of the gastrointestinal tract. Front RadiatTherOncol 1988, 22:127-148.

13. Williams IG: Radiotherapy of carcinoma of the rectum. In Dukes C, ed. Cancer of the Rectum. E\&S Livingston, Edinburgh 1960, 210-219.

14. Whiteley HW Jr, Stearns MW Jr, Leaming RH, Deddish MR: Radiation therapy in the palliative management of patients with recurrent cancer of the rectum and colon. SurgClin North Am 1969, 49:381-387.

15. Moertel CG, Childs DS Jr, Reitemeier RJ, Colby MY Jr, Holbrook MA: Combined 5-fluorouracil and supervoltage radiation therapy of locally unresectable gastrointestinal cancer. Lancet 1969, 2(7626):865-867.

16. Urdaneta-Lafee N, Kligerman MM, Knowlton AH: Evaluation of palliative irradiation in rectal carcinoma. Radiology 1972, 104:673-677.

17. Wang CC, Schulz MD: The role of radiation therapy in the management of carcinoma of the sigmoid, rectosigmoid, and rectum. Radiol 1962, 79:1-5.

18. Gunderson LL, Cohen AM, Welch CW: Residual, inoperable, or recurrent colorectal cancer: surgical radiotherapy interaction. Am J Surg 1980, 139:518-525

19. O'Connell MJ, Childs DS, Moertel CG, Holbrook MA, Schutt AJ, Rubin J, Ritts RE Jr: A prospective controlled evaluation of combined pelvic radiotherapy and methanol extraction residue of BCG (MER) for locally unresectable or recurrent rectal carcinoma. Int J RadiatOncolBiolPhys 1982, 8(7):1115-1119.

20. Rominger CJ, Gunderson LL, Gelber RD, Conner N: Radiation therapy alone or in combination with chemotherapy in the treatment of residual or inoperable carcinoma of the rectum and rectosigmoid or pelvic recurrence following colorectal surgery. Radiation Therapy Oncology Group study (76-16). Am J ClinOncol 1985, 8:118-127.

21. Lingareddy V, Ahmad NR, Mohiuddin M: Palliative reirradiation for recurrent rectal cancer. Int J RadiatOncol Biol Phys 1997, 38(4):785-90.

22. Crane CH, Janjan NA, Abbruzzese JL, Curley S, Vauthey J, Sawaf HB, Dubrow R, Allen P, Ellis LM, Hoff $P$, Wolff RA, Lenzi R, Brown TD, Lynch $P$, Cleary K, Rich TA, Skibber J: Effective pelvic symptom control using initial chemoradiation without colostomy in metastatic rectal cancer. Int J Radiat Oncol Biol Phys 2001, 49(1):107-16.

23. Mohiuddin M, Marks G, Marks J: Long-term results of reirradiation for patients with recurrent rectal carcinoma. Cancer 2002, 95(5):1144-50.

24. Poultsides GA, Servais EL, Saltz LB, Patil S, Kemeny NE, Guillem JG, Weiser M, Temple LK, Wong WD, Paty PB: Outcome of primary tumor in patients with synchronous stage IV colorectal cancer receiving combination chemotherapy without surgery as initial treatment. J Clin Oncol 2009, 27(20):3379-84, Epub 2009 Jun 1.

25. Cameron S, Hünerbein D, Mansuroglu T, Armbrust T, Scharf JG, Schwörer H, Füzesi L, Ramadori G: Response of the primary tumor in symptomatic and asymptomatic stage IV colorectal cancer to combined interventional endoscopy and palliative chemotherapy. BMC Cancer 2009, 9:218.

26. Kim MM, Rana V, Janjan NA, Das P, Phan AT, Delclos ME, Mansfield PF, Ajani JA, Crane CH, Krishnan S: Clinical benefit of palliative radiation therapy in advanced gastric cancer. ActaOncol 2008, 47(3):421-7.

27. Coia LR, Soffen EM, Schultheiss TE, Martin EE, Hanks GE: Swallowing function in patients with esophageal cancer treated with concurrent radiation and chemotherapy. Cancer 1993, 71(2):281-6.

28. Burmeister BH, Denham JW, O'Brien M, Jamieson GG, Gill PG, Devitt P, Yeoh E, Hamilton CS, Ackland SP, Lamb DS, Spry NA, Joseph DJ, Atkinson C, Walker QJ: Combined modality therapy for esophageal carcinoma: preliminary results from a large Australasian multicenter study. Int J RadiatOncolBiolPhys 1995, 32(4):997-1006.
29. Hayter CR, Huff-Winters C, Paszat L, Youssef YM, Shelley WE, Schulze K: A prospective trial of short-course radiotherapy plus chemotherapy for palliation of dysphagia from advanced esophageal cancer. RadiotherOncol 2000, 56(3):329-33.

30. Harvey JA, Bessell JR, Beller E, Thomas J, Gotley DC, Burmeister BH, Walpole ET, Thomson DB, Martin I, Doyle L, Burmeister E, Smithers BM: Chemoradiation therapy is effective for the palliative treatment of malignant dysphagia. Dis Esophagus 2004, 17(3):260-5.

31. Kaplan EL, Meier P: Non-parametric estimation from incomplete observations. J Am Statisticians Assoc 1958, 53:457-481.

32. Harris E, Albert A: Survivorship analysis for clinical studies. New York, NY, Dekker; 1991.

33. Emami B, Lyman J, Brown A, Coia L, Goitein M, Munzenrider JE, Shank B, Solin $L$, Wesson M: Tolerance of normal tissue to therapeutic irradiation. Int J RadiatOncolBiolPhys 1991, 21:109-122.

34. Nieder C, Milas L, Ang KK: Tissue tolerance to reirradiation. Semin Radiat Oncol 2000, 10(3):200-9.

35. Wong CS, Cummings BJ, Keane TJ, Dobrowsky W, O'Sullivan B, Catton CN: Combined radiation therapy, mitomycin $C$, and 5-fluorouracil for locally recurrent rectal carcinoma: results of a pilot study. Int J Radiat Oncol Biol Phys 1991, 21(5):1291-6.

36. Tey J, Back MF, Shakespeare TP, Mukherjee RK, Lu JJ, Lee KM, Wong LC, Leong CN, Zhu M: The role of palliative radiation therapy insymptomatic locally advanced gastric cancer. Int J RadiatOncolBiolPhys 2007, 67(2):385-8, Epub 2006 Nov 21.

doi:10.1186/1748-717X-6-52

Cite this article as: Bae et al.: Palliative radiotherapy in patients with a symptomatic pelvic mass of metastatic colorectal cancer. Radiation Oncology 2011 6:52.

\section{Submit your next manuscript to BioMed Central and take full advantage of:}

- Convenient online submission

- Thorough peer review

- No space constraints or color figure charges

- Immediate publication on acceptance

- Inclusion in PubMed, CAS, Scopus and Google Scholar

- Research which is freely available for redistribution

Submit your manuscript at www.biomedcentral.com/submit
Biomed Central 